\title{
A Hard Nut to Crack: Macadamia in Hawaii
}

\author{
David Rietow ${ }^{1}$ \\ Agro Resources Hawaii, P.O. Box 2933, Kamuela, HI 96743 \\ Additional index words. Macadamia integrifolia, nut industry
}

\begin{abstract}
The macadamia nut (Macadamia integrifolia) was introduced to Kapulena on the Hamakua Coast of Hawaii from Australia in 1881 by William Purvis. The first commercial plantation was established in Oahu but the commercial industry moved to Hawaii, the Big Island. By 1950, the largest producer was the Honakaa Sugar Company with 450 acres (182 ha). The development of new technology, including the selection of cultivars on grafted trees, resulted in an expansion of the industry. The Mauna Loa Company is now the world's largest grower, processor, and marketer of macadamia nuts with over 10,000 acres $(4047 \mathrm{ha})$. The industry now consists of $\approx \mathbf{5 0 0}$ to 600 growers that are connected by ownership or contract to the two largest processor/marketers, Mauna Loa and Mac Farms. The Hawaiian macadamia industry is now relatively static. Crop area peaked in 1990 at 22,600 acres $(9146 \mathrm{ha})$ and then gradually dropped to 17,000 acres (6880 ha) in 2006 where it has remained. In-shell nut production during the same period ranged from a low of 40 million pounds $(18,148 \mathrm{t})$ in this past crop year (2010-11) to a high of 58 million pounds (26,315 t) in 2006-07. Competition among Hawaii, Australia, and Africa is now intense.
\end{abstract}

The year was 1881. Kalakaua was king and Hawaii was still a peaceful monarchy. A man named William Purvis arrived from Australia on a steamship that year bringing with him the first macadamia tree to Hawaii. At that time, Purvis was a 23-year-old avid plant collector and sugar plantation manager on the island of Hawaii. He planted the tree in the sleepy plantation town of Kapulena on the island's Hamakua Coast. Many years ago when I was farming macadamia orchards at Kapulena, I went with a local resident who knew where the tree was planted to see it for myself. I believe that it is still there today.

The macadamia was first classified and described in 1858 by Baron Sir Ferdinand Jakob Heinrich von Mueller, director of Australia's Melbourne Botanical Gardens, and Walter Hill, superintendent of Brisbane's Botanical Gardens. The nut was named in honor of Mueller's good friend, John Macadam, a prominent scientist, philosopher, and politician.

The macadamia tree, a subtropical evergreen of the Proteaceae (Hardner et al., 2009; Nagao, 2008), has two species that produce edible nuts: Macadamia integrifolia and Macadamia tetraphylla. Both have dark green hollylike leaves and can reach a height of $40 \mathrm{ft}$ or more.

Macadamia integrifolia, known as smoothshell macadamia, has proved suitable for commercial production. Macadamia tetraphylla, the rough-shell macadamia, has proved unsuitable and produces nuts of inconsistent quality.

The first commercial planting of macadamia is credited to Ernest Shelton van Tassel. He planted the first macadamia plantation on 75 acres of land on Tantalus, Oahu, and founded the Hawaiian Macadamia Nut

\footnotetext{
Received for publication 13 June 2012. Accepted for publication 31 Aug. 2012.

This paper was part of the workshop "History of Hawaiian Pomology" held 25 Sept. 2011 at the ASHS Conference, Waikoloa, HI, and sponsored by the History of Horticultural Science (HIST) and Pomology (POM) Working Groups.

${ }^{1}$ To whom reprint requests should be addressed; e-maildavid@agroresources.com.
}

Company. Oahu Island was not to be the future home of Hawaii's macadamia industry, rather Hawaii Island with its vast land mass suitable for an orchard crop such as macadamia would ultimately become the center of production. van Tassel chose Keauhou, Kona, on the leeward side of the island to expand his business. In 1924 he leased $\approx 100$ acres (40 ha) in Keauhou and planted 7000 trees. To market his product, he established a commercial processing facility in Honolulu and sold his macadamia nuts, in glass jars, to selected shops on the U.S. mainland. During the same timeframe, Walter Naquin began planting macadamia trees on the other side of the island near Honokaa. By 1950, his employer, Honokaa Sugar Company, was the largest producer of macadamia nuts in the territory of Hawaii with $\approx 450$ acres (182 ha) of trees planted.

\section{DEVELOPMENT OF THE HAWAIIAN INDUSTRY}

As the industry began to mature, it became evident that trees planted from seed-produced trees varied greatly, including variable nut production and kernel quality. Great contributions to the industry were made by the University of Hawaii's College of Agriculture and the Hawaii Agricultural Experiment Station (Hamilton and Fukunaga, 1959; Moltzau and Ripperton, 1939; Shigeura and Ooka, 1984). The resulting plant breeding program established by the University of Hawaii developed the cultivars that are currently used in the industry today. Grafted trees replaced seedlings and both orchard yield and kernel quality improved dramatically.

With the development of reliable grafted tree cultivars and increased marketing efforts that promoted the awareness of the macadamia as the "perfect nut," Hawaii's larger agricultural companies began to look at diversifying and macadamia was the obvious choice. In 1948, Castle \& Cooke, Inc. planted 1000 acres (405 ha) in Keaau and marketed their product under the Royal Hawaiian label. C. Brewer \& Company followed Castle \& Cooke into the macadamia business, eventually purchasing Castle \& Cooke's macadamia interests, and established Mauna Loa Macadamia Nut Company. Mauna Loa became the world's largest grower, processor, and marketer of macadamia nuts with over 10,000 acres (4047 ha) of macadamia, all on the island of Hawaii. Other companies soon followed.

Hawaiian Holiday Macadamia Nut Company. Paul DeDominico of Hawaiian Holiday Macadamia Nut Company established large orchards in both Kohala and Keaau through a series of limited partnerships. Paul and his wife, Anita, were pioneers in product development and marketing. The company eventually went bankrupt and sold its processing and manufacturing equipment to Hamakua Macadamia Nut Company.

Mac Farms of Hawaii. In 1960, Willis Jennings leased 4200 acres in South Kona from the Bishop Estate and through limited partnerships established a macadamia orchard under the management of Kona Property Management, Inc. The orchards and the management company were sold in 1977 to Mac Farms of Hawaii, Inc. Under Mac Farms, the operation became fully integrated with the establishment of processing, manufacturing, and marketing functions. The product was sold under the Mac Farms label. Mac Farms was the first to use the pouch, rather than a jar or can, as a container. The significance of the pouch was reduced materials shipping cost because all packing materials came from the U.S. mainland.

Hawaiian Host Candies. The company developed a loyal grower following on both sides of the Hawaii Island and built receiving stations along with small processing facilities that produce kernel for their manufacturing plant in Honolulu. They are currently the leader in combining macadamia nuts with chocolate to produce many tasty retail products.

Island Princess. The company is comprised of a 1000-acre orchard and processing facility in Keaau. The manufacturing facility and corporate office are in Honolulu.

Hamakua Macadamia Nut Company. The company is located in Kawaihae, buys nuts from growers around Hawaii Island, and processes and manufactures the nuts into both bulk kernel and retail products. The company 
sells its retail products under the Hamakua Plantations label.

The importance of a stable processor/ marketer community is that it provides the necessary vehicle for the small macadamia grower to exist and prosper during most years. As the result, the Hawaiian industry has, at any one time, between 550 and 600 growers that range in size from several acres to thousands of acres (Table 1). The larger orchards are connected by ownership or contract to the two largest processor/marketers, Mauna Loa and Mac Farms. The independent orchards contract with the processor of their choice, generally based on the price and location.

Another important component of the industry is the ownership of these key processor/ marketers. During the industry's development and through the early 1980 s, the companies that were planting the orchards and developing the processing and marketing facilities had their roots in Hawaii. As macadamia became a global commodity and many companies worldwide were diversifying, corporate entities from both the U.S. mainland and foreign countries became interested in macadamia from Hawaii. This interest resulted in two significant changes in the industry: consolidation and reorganization.

\section{CONSOLIDATION AND REORGANIZATION OF THE INDUSTRY}

The first consolidation of the macadamia industry was the sale of Mac Farms of Hawaii to CSR of Sydney, Australia, in 1981. Mac Farms has had a series of owners after the CSR acquisition, which include Blue Diamond (almond cooperative) and Campbell Soup through an Australian subsidiary. Mac Farms is currently Australian-owned.

The second was the reorganization of Mauna Loa Macadamia Nut Company into two separate business entities, an orchard company and a processing/marketing company. In 1986 Mauna Loa Partners (the orchard company) became a publicly traded limited partnership. It would eventually be renamed ML Macadamia Orchards L.P. In 2000, Mauna Loa (the processing/marketing company) was sold to The Shansby Group, a private equity group from San Francisco. In 2004, Shansby sold Mauna Loa to The Hershey Company.

The result of these transactions was to place the ownership of the industry's two largest processors under "foreign" ownership. This changed the dynamics of the industry's relationship between the growers and the major processors. There was no synergistic relationship where each needed the other to be economically successful. The growers were

Table 1. Distribution of growers by crop area.

\begin{tabular}{lcc}
\hline $\begin{array}{l}\text { Size } \\
\text { (acres) }\end{array}$ & $\begin{array}{c}\text { Grower } \\
\text { distribution }(\%)\end{array}$ & $\begin{array}{c}\text { Total } \\
\text { area }(\%)\end{array}$ \\
$\leq 1$ & 30 & 1 \\
$2-5$ & 45 & 7 \\
$6-19$ & 19 & 7 \\
$\geq 20$ & 6 & 85 \\
\hline
\end{tabular}

still dependent on the processor, but the processor had the option of purchasing kernel from other parts of the world. Loyalty to the Hawaiian macadamia industry as well as the promotion of the Hawaiian nut was on its way out.

In the period that followed these significant changes in the structure of the industry, the small grower suffered financially from the vagaries of a worldwide commodity market. They became a captive audience to the direction the Hawaiian industry was taking. A casualty of this shift was the Hawaii Macadamia Nut Association. Its mandate was to provide industry members with a forum to discuss and create solutions for problems as well as create a unified direction for the Hawaiian macadamia industry. The major areas to be addressed by the association were 1) cultivation research and development to include a cultivar improvement program; 2) farm equipment design with emphasis on mechanical harvesting; 3) processing equipment innovation; and 4) generic promotion of the Hawaiian macadamia nut.

To accomplish these goals, the association was the industry's partner in getting grants, working with the University of Hawaii and the USDA's Pacific Basin Agricultural Research Center (PBARC) to manage research and development projects. Industry funding came from a voluntary assessment program in which annual contributions were made to the association by its members based on the amount of crop harvested and processed.

This voluntary assessment program worked while all of the industry was represented by local ownership. As soon as the ownership of Mac Farms and Mauna Loa changed, the majority of the funding ceased and the association did not have adequate funding to continue with its projects. Most projects required a funding ratio of $1: 1$ between the industry and the entity providing the grant. The Hawaii Macadamia Nut Association is currently inactive.

\section{MACADAMIA CULTIVATION AND PRODUCTION}

The water requirement for macadamia is 60 inches $(152 \mathrm{~cm})$ of rainfall or the equivalent irrigation. It is generally planted at between $500(152 \mathrm{~m})$ and $1000 \mathrm{ft}(305 \mathrm{~m})$ in elevation and needs relatively dry weather during flowering and nut set to prevent abortion resulting from fungus organisms.

The most common spacing is $30 \mathrm{ft}(9.1 \mathrm{~m})$ between rows, $15 \mathrm{ft}(4.5 \mathrm{~m})$ between trees in a row, which provides for 96 trees/acre (237 trees/ha). Older orchards in Hawaii were planted at $30 \mathrm{ft}$ by $30 \mathrm{ft}$, providing for 48 trees/acre (119 trees/ha).

The most common cultivation operations for macadamia in Hawaii are as follows: mowing, herbicide spraying (glyphosate) under the tree rows, fertilizing four times per year, irrigation (where required), pruning and leaf blowing to assist with harvesting, pest control (primarily rats), and leaf tissue analysis to monitor nutrient uptake, which assists with fertilizer determination.

The macadamia is very similar to other orchard nut crops. The tree produces a nut that is generally allowed to mature on the tree and fall to the ground where it is harvested either by hand or by machine. Processing of the nut entails removing the outer husk, removing most of the moisture from the inshell nut through a drying process, cracking the dry in-shell nut, separating the shell from the kernel, roasting and grading followed by bulk packaging. The manufacturing process begins with one or more grades of bulk kernel and ends with a retail product. Some of the smaller grades will be used in other products as an ingredient. Some examples of this are ice cream, cookies, and cakes. Macadamia oil is made from unusable nuts and nut pieces.

Orchard production and kernel recovery, in very general terms, are outlined subsequently. Production will vary with tree age and location. Quality will vary from orchard to orchard depending on climate, cultivar, and cultivation practices.

- A mature orchard will yield between 4000 and $6000 \mathrm{lb}$ of nut-in-shell/acre (4500 and $6700 \mathrm{~kg} \cdot \mathrm{ha}^{-1}$ ).

- One hundred pounds $(45.3 \mathrm{~kg})$ of nut-inhusk harvested will yield $50 \mathrm{lb}(22.6 \mathrm{~kg})$ of nut-in-shell at field moisture $(20 \%)$.

- Fifty pounds of nut-in-shell $(22.6 \mathrm{~kg})$ at field moisture will yield $41 \mathrm{lb}(18.6 \mathrm{~kg})$ of dry-in-shell (1.5\% moisture).

- Forty-one pounds of dry-in-shell nuts (18.6 kg) will yield $10 \mathrm{lb}(4.5 \mathrm{~kg})$ of kernel.

The nutritional content of the macadamia kernel is as follows: protein $(9.2 \%)$, fat $(78.2 \%)$, carbohydrate $(10.0 \%)$, and vitamins and minerals $(2.6 \%)$. The fatty acid profile of the macadamia kernel is as follows: monounsaturated $(82.5 \%)$, saturated $(15.7 \%)$, and polyunsaturated $(1.8 \%)$

\section{CURRENT VALUE OF THE INDUSTRY}

The macadamia industry in Hawaii currently has 570 growers farming 17,000 acres (6882 ha) that produce 40 million pounds $(18,148 \mathrm{t})$ of in-shell nuts valued at $\$ 30$ million. The industry value is understated statistically because in-shell nuts are not generally sold in either the industrial or retail markets. The nut is sold to industrial markets in the form of bulk kernels, usually packaged in $25-1 b(11.3 \mathrm{~kg})$ foil-lined boxes. In retail markets, kernel is sold in a variety of products that include roasted and salted, candy or chocolate-coated, in various packages, cans or jars. Therefore, the industry value based on kernel sales alone is significantly undervalued.

If some general assumptions are made, the kernel value of the industry can be calculated. First the in-shell nut is dried from field moisture at $20 \%$ to $1.5 \%$ moisture at which point the nut is cracked. The shell is then removed leaving the edible kernel. The recovery of 
kernel to the in-shell nut averages $\approx 28 \%$. So the 40 million pounds of in-shell nuts would lose $18.5 \%$ of its weight to moisture then weigh 32.6 million pounds. The edible kernel at $28 \%$ recovery would weigh 9.1 million pounds. If the average sales price for the kernel is $\$ 6.00$ /pound, then the annual macadamia production is worth $\$ 54.6$ million rather than the reported $\$ 30$ million. The retail value of the industry, depending on the ratio of retail products sold to industrial sales of bulk kernel, is somewhere in excess of $\$ 100$ million.

It is interesting to note that processing of the macadamia nut makes very efficient use of both kernel and byproducts.

- All grades (sizes) of kernel, even kernel dust, are sold as either a retail macadamia product or for industrial use as an ingredient of another product (used in ice cream and cookies as an example).

- Cull kernel is pressed for macadamia oil. The oil has high flash point and a mild taste making it excellent for cooking.

- The outer husk of the macadamia is used for compost.

- The shell is burned in a furnace to produce heat for drying the incoming nut-in-shell. Larger processors also used the steam produced by the furnace to produce electricity. A new company on the island of Hawaii is buying macadamia shell and converting it to activated charcoal.

\section{THE FUTURE}

The macadamia industry in Hawaii today is comprised of five major processors and they are, in order of size:

- Mauna Loa Macadamia Nut Company. Mauna Loa retail product. Contract processes the Kirkland labeled products for Costco.

- Mac Farms of Hawaii. Mac Farms retail product. Sells bulk kernel into the U.S. industrial market.

- Hamakua Macadamia Nut Company. Hamakua Plantations retail product.

- Hawaiian Host. Hawaiian Host retail product. Sells both roasted salted macadamia and chocolate-covered retail product.

- Island Princess. Island Princess retail product.

Mauna Loa and Island Princess are on the east side of the island of Hawaii. Mac Farms and Hamakua Macadamia Nut Company are located on the west side. Hawaiian Host has two small processing facilities on the island, one on the east side and one on the west side. There are several smaller regional processors as well.

If one looks at statistics, the Hawaiian macadamia industry has been relatively static. The in-crop area in 1984 was 17,500 acres (7082 ha). The crop area peaked in 1990 at 22,600 acres (9146 ha) and then gradually dropped to 17,000 acres (6880 ha) in 2006 where it has remained. Net in-shell production during the same period ranges from a low of 40 million pounds $(18,148 \mathrm{t})$ in this past crop year (July 2010 to June 2011) to a high of 58 million pounds $(26,314 t)$ in the 2006-07 crop year.

Statistics are valuable, but they become an afterthought when it comes to what drives an industry to either prosper or decline. From the grower standpoint, it is a combination of weather and the farm price for nut-in-shell. As we know from the current weather trends on the U.S. mainland, weather to the farmer can be everything but it is not something we can control. In Hawaii, we have the Pacific Ocean as a buffer and therefore do not have the wide changes in weather that farmers on the U.S. mainland are currently experiencing. Hawaii's macadamia production fluctuations resulting from weather are within the range of $\pm 10 \%$.

The most significant impact on the macadamia grower is the nut-in-shell price. There is a "bottom" price for each grower at which farming is not economically viable and the industry seems to fall into this price range on a relatively consistent cycle of about five to six years. It is very difficult to sustain a farming business under this cyclic pricing and this is probably why the Hawaiian industry has been relatively static over the past 25 years or so.

So what causes this cyclic fluctuation? The change in the macadamia from a cottage market product of the Hawaiian macadamia nuts to a world commodity is one. In the mid-1970s, Hawaii produced $\approx 95 \%$ of the world's macadamia kernel. Today Africa is the number one producer followed by Australia (Table 2). Hawaii is the third largest producer with $\approx 16 \%$ of world kernel production. The change in ownership of the two largest brands, Mauna Loa and Mac Farms, is another. With international ownership and a world supply of kernel, price became the driver.

What has happened over time is that both Australia and Africa have continued to plant macadamia orchards and Hawaii has not. When production is good in these continents, world production tends to exceed demand and the world price of kernel goes down. When weather conditions in either or both of the top-producing regions negatively impact production, the price goes up.

The other market driver is consumption. The primary market for the macadamia nut is the United States followed by Europe and then Asia. During years of high production, the kernel price is relatively low, inducing manufacturers to use macadamia kernel in retail product lines or in mixed nut products. This increased consumption does not dissipate during low nut production years. The resulting competition for kernel by the manufacturers equates to higher nut-in-shell prices to the grower.

What are possible solutions to providing for a more stable economic environment from the Hawaiian industry point of view?

1. Reduce the cost of farming. This is difficult with the continued rise in the
Table 2. World kernel production in 2011.

\begin{tabular}{lcc}
\hline Region & Kernel (tonnes) & Percent \\
\hline Hawaii & 3,890 & 14.1 \\
Australia & 9,914 & 36.0 \\
Africa & 10,916 & 39.6 \\
Latin America & 2,854 & 10.4 \\
Total & 27,574 & 100.0 \\
\hline
\end{tabular}

cost of petroleum-related items such as fertilizer, pesticides, and equipment, but there is an opportunity in harvesting. Harvesting is a significant cost of macadamia production primarily as a result of lack of mechanization of the process by the smaller grower. Australian pinwheel harvesting technology has made it possible for the small grower to become mechanized with a low capital investment.

2. Plant improvement. The University of Hawaii's cultivar research program has fallen by the wayside as a result of cuts in funding and the industry is unable to fund the program on its own. However, new cultivars that provide for higher production and recovery as well as disease resistance would effectively reduce the cost of production per unit area.

3. Manufacturing innovation. Current robotics technology and computerized production lines would reduce the cost of processing and manufacturing. New manufacturing technology is beginning to see its way into the industry's processing and manufacturing facilities. A good example of this is the optic sorter that removes shell from kernel.

4. Balanced marketing (sales). A balance between high margin retail sales and lower margin industrial sales that provides the manufacturer with an overall higher net price per kernel pound would allow for a higher price paid to the grower for nut-in-shell. The basis for a healthy Hawaiian macadamia industry is a financially healthy grower base.

Hawaii may not have "invented" the macadamia tree, but it became the home of an industry that has provided the "perfect nut" to many people worldwide. We are proud of our contribution.

\section{Literature Cited}

Hamilton, R.A. and E.T. Fukunaga. 1959. Growing macadamia nuts in Hawaii. Hawaii Agr. Expt. Sta. Bul. 121.

Hardner, C.M., C. Peace, A.J. Lowe, J. Neal, P. Pisanu, M. Powell, A. Schmidt, C. Spain, and K. Willliams. 2009. Genetic resources and domestication of macadamia. Hort. Rev. 35:1-125.

Moltzau, R.H. and J.C. Ripperton. 1939. Processing of the macadamia. Hawaii. Agr. Expt. Sta. Bul 83.

Nagao, M.A. 2008. Macadamia integrifolia macadamia nut, p. 600-610. In: Janick, J. and R.E. Paull (eds.). Encyclopedia of fruit and nuts. CABI, Wallingford, UK.

Shigeura, G.T. and H. Ooka. 1984. Macadamia nuts in Hawaii: History and production. Hawaii Inst. Trop. Agr. Ext. Ser. 39. 